\title{
Fostering inclusion, embracing and integration of migrants: A migration biblical-theological understanding with a particular focus on Ezra- Nehemiah and migrants practical ministry guidelines
}

\begin{tabular}{|c|c|}
\hline \multicolumn{2}{|c|}{$\begin{array}{l}\text { Authors: } \\
\text { Vhumani Magezi }{ }^{1} \\
\text { Christopher Magezi }{ }^{1}\end{array}$} \\
\hline \multicolumn{2}{|c|}{$\begin{array}{l}\text { Affiliations: } \\
{ }^{1} \text { Unit for Reformational } \\
\text { Theology and the } \\
\text { Development of the South } \\
\text { African Society, Faculty of } \\
\text { Theology, North-West } \\
\text { University, Potchefstroom, } \\
\text { South Africa }\end{array}$} \\
\hline \multicolumn{2}{|c|}{$\begin{array}{l}\text { Corresponding author: } \\
\text { Vhumani Magezi, } \\
\text { vhumani@hotmail.com }\end{array}$} \\
\hline \multicolumn{2}{|c|}{$\begin{array}{l}\text { Dates: } \\
\text { Received: } 17 \text { Dec. } 2019 \\
\text { Accepted: } 23 \text { Apr. } 2020 \\
\text { Published: } 06 \text { July } 2020\end{array}$} \\
\hline \multicolumn{2}{|c|}{$\begin{array}{l}\text { How to cite this article: } \\
\text { Magezi, V. \& Magezi, C., } \\
\text { 2020, 'Fostering inclusion, } \\
\text { embracing and integration } \\
\text { of migrants: A migration } \\
\text { biblical-theological } \\
\text { understanding with a } \\
\text { particular focus on } \\
\text { Ezra-Nehemiah and migrants } \\
\text { practical ministry guidelines', } \\
\text { In die Skriflig 54(1), a2591. } \\
\text { https://doi.org/10.4102/ids. } \\
\text { v54i1.2591 }\end{array}$} \\
\hline \multicolumn{2}{|c|}{$\begin{array}{l}\text { Copyright: } \\
\text { ( ) 2020. The Authors. } \\
\text { Licensee: AOSIS. This wo } \\
\text { is licensed under the } \\
\text { Creative Commons } \\
\text { Attribution License. }\end{array}$} \\
\hline \multicolumn{2}{|l|}{ Read online: } \\
\hline 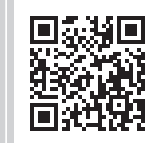 & $\begin{array}{l}\text { Scan this QR } \\
\text { code with your } \\
\text { smart phone or } \\
\text { mobile device } \\
\text { to read online. }\end{array}$ \\
\hline
\end{tabular}

Migration is posing a huge challenge globally. Within this context, one of the challenges of theology is to develop theological approaches that respond to the situation in meaningful ways. There is increasing scepticism about some theological frameworks that attempt to consider the Bible and theology as a unified whole to provide coherence. In the midst of vexatious life challenges, people require coherence, logic and guidance in their existential situations. Notably, the notion of logic and coherence could be pathological in chaotic global situations where cause and effect seems not to hold. In such situations, the article argues that a responsive theological approach, which draws from the Bible, should engage a panoramic and systemic schema that take into account the various dynamics of people's situations. In consideration of the subject of migration, a biblical redemptive historical theological schema is applied to Ezra-Nehemiah to discern a constructive and coherent understanding on texts that appear to encourage xenophobia in order to guide practical ministry. Implied in the article is a contention for maintaining diverse theological frameworks based on their utility, but subjecting such frameworks to academic and critical rigour to avoid the danger of fundamentalism. The article locates and problematises migration as a theological issue and then discusses the rationale for a redemptive historical framework. The framework is then applied to EzraNehemiah, resulting in concrete lessons that guide practical ministry.

Keywords: migrants integration; Ezra-Nehemiah; migration biblical-theological understanding; redemptive historical approach; migrants ministry; migrant inclusion.

\section{Introduction and study background: Terrain sketch and problem identification}

The number of people engaging in international migration has rapidly increased over the past few years (International Organisation for Migration [IOM] 2015:1). When people voluntarily and involuntarily move from their countries of origin to their preferred countries of destination due to various factors, they are confronted with multifaceted and complex challenges that the church, as a community of God, is expected to address (Magezi 2017; Snyder 2012). The problem that has emerged is that, while the church has a role to perform in a responsible migration response that is driven by its comprehensive theology of migration (Magezi 2017), it is apparent that the Bible, if not handled appropriately, can possibly limit the churches' participation in responding to migrants' challenges (Snyder 2012:136ff.). Snyder (2012:136ff.) advances that the Bible seems to have mixed attitudes towards foreigners or outsiders, that is, it points to the inclusion and separation of outsiders. That is, on one hand, the Bible presents the notion of the inclusion of foreign nationals within the Israelite community, that is, the inclusion of Tamar (Gn 38), Rahab (Jos 2:1-21), Ruth (Rt 1-4), the Gibeonites in Joshua 9-10, et cetera. (Magezi 2018:52-64). On the other hand, it presents the exclusion of foreigners or outsiders among the Israelites. According to Snyder (2012:143), Ezra-Nehemiah is 'one of a number of biblical texts which could be used to justify the exclusion of outsiders' (Snyder 2012:143). In Snyder's view (2012:140), Ezra 9:1-4, 1012 'denounces marriages of Israelites with the people of the lands in unambiguous terms', while Ezra 10:11 'demands that the people of Judah make confession and separate themselves from the peoples of the land and foreign wives'. This has generated mixed conclusions among biblical scholars and commentators regarding the book of Ezra-Nehemiah (Usue 2012:158). For instance, Williamson (1985:159) contends that the command for the Israelite men who returned from the

Note: Special Collection: Law and Justice Conference 
Babylonian captivity to divorce foreign women is 'among the least attractive parts of Ezra-Nehemiah, if not of the whole Old Testament'. Schwartz (1997:86) describes Ezra 9:11-12 as 'the most xenophobic utterance' the Bible makes 'about drawing the border of Israel by kinship'. Usue $(2012: 158,167)$ charges Ezra and his associates with having a narrow view of the Abrahamic and Mosaic covenant codes and concludes that the women were not foreigners as stipulated by EzraNehemiah. Snyder (2012:141) also perceives Ezra-Nehemiah as a xenophobic text as she advances that 'Ezra-Nehemiah appears to be a profoundly xenophobic text'. It is a text that could be taken as an 'encouragement to ignore newcomers at best and positively seek their removal from local and national communities at worst'.

Emerging from the abovementioned discussion is the notion that Ezra-Nehemiah is considered as a xenophobic text. In the view of this article, this perception of Ezra-Nehemiah is interconnected with the notion that the Bible constitutes some verses and sections that may seem to contradict with the wider message of Scripture (Demarest \& Lewis 1987:132). This conception of Scripture has a lesser view of the doctrine of inspiration that argues that Scripture came into existence as a result of divine-human collaboration. However, God superintended the whole process through the Holy Spirit so that the writings could be designated as the authentic Word of God (Demarest \& Lewis 1987:132ff.; Horton 2011:167ff.; Murray n.d.:73-104). Indeed, if God superintended the whole process and he is the author of Scripture through human beings as his agents, it is certain that Scripture does not err or contradict itself as God, by nature, does not err or contradict himself (Horton 2011:167ff.). Together with other scholars in systematic theology such as Horton (2011), indicated above, this article argues that God is consistent and so is Scripture, which reveals him (God). From this position, the perceived contradictions require one to adopt a framework that embraces this position in a manner that is cognisant of its limitations within a scholarly debate.

In view of the above migration situation, theology, like any other discipline, should be involved in developing a response to address migration. To bring theology into this conversation, the question that arises is: How should theology be involved? Miller-Mclemore and Couture (2003), introducing the book volume at the International Academy of Practical Theology at Stellenbosch, South Africa, poses crucial and fundamental questions for theology, which are relevant to current migration discussions:

How do the churches relate to society? What does the problem of global and local poverties mean for the practices of ministry within the church? And how are these relationships and practices grounded in biblical and theological perspectives? (p. xi)

These questions relate to the function of church and theology within the realm of real life. The questions that could be posed to extrapolate the questions of Miller-Mclemore and Couture (2003) in the migration context under consideration should, among other things, focus on the Bible, church and society. The questions include the following: How is the situation of migration broadly portrayed in the Bible?; How can one read, interpret and make meaning of migration issues, resulting in practical guidelines?; and What biblical frameworks could provide a lens into discerning constructive and meaningful understanding of migration in the Bible? At stake is the question: How do theology scholars depart from mere theoretical and sometimes fragmented theological understanding to coherent theological understanding to instil meaning, logic, sense and purposefulness in people's lives? A response to these questions requires integrated theological thinking. Integrated theological thinking is about adopting a systemic approach to doing theology. One cannot engage a life issue such as migration from a mono- or linear approach (cf. Louw 2014).

Various theological disciplines need to be considered together to provide an integrated understanding. For instance, in our case, developing a theological understanding of migration from the Bible is certainly a systematic-theological endeavour where one pulls together various texts to make meaning and discern their connections. At the same time, these biblical texts need to be understood from and within their respective contexts. As one brings systematic theology and biblical texts to discern a biblical understanding, the issue that further emerges is their practical relevance to a topical and practical issue such as migration.

\section{Quest for a framework in migration theology: A biblical redemptive historical approach}

A relevant and responsible approach to understanding and developing migration theology, as well as ministry guidelines, requires a constructive theological approach. Magezi and Magezi (2018:1) define a constructive theological approach as referring to 'functional theology that responds to the needs of people. A constructive and sound theology refers to theology that is useful and able to address people's needs'. The constructive approach is not concerned with the issue of right or wrong in the approach, but about whether it is justifiable or not. It is about making effort to determine whether a theological thinking could be sustained from the Bible. At stake in a constructive approach is the question: Does the approach represent God as presented in the Bible? The notion of a constructive Bible framework is closely related to what Louw (2014:276) calls speaking appropriately on God within different contexts (representative speaking).

The constructive approach is therefore an integrative reflection process that draws from the various theological disciplines, particularly in the case concerning biblical, systematic and practical theology. Miller-McLemore and Couture (2011:14), and Graham (2017:3) clarify that practical theology is distinguished from systematic theology that is orderly beliefs about God, the church or classical texts or biblical studies, which focus on interpreting biblical texts. Practical theology regards practice as significant in a 
theological process. However, context and the reality of lived experiences are critical departure points (Graham 2017:3). Selecting the constructive approach from multiple approaches is like choosing food from a 'buffet' table. One selects the food which meets one's intentions and goal. However, within an academic context, the selected approach should be rigorous.

The approach of speaking appropriately on God, as suggested by Louw (2014), is not the only one. Braaten (1989) identifies three different contexts that influence how people speak of God today, namely the ecclesial, the academic and the secular. Louw (2014) encapsulates Braaten's (1989) three modes of God's language in the following manner:

The first mode is that of the academic. Its concern and inquiry is to speak about the character and being of God; Braaten calls it a descriptive monological approach. The second refers to the dialogical mode of prophecy and proclamation, i.e. speaking for God, which is a prescriptive task. The third is the liturgical mode of speaking to God in prayer and praise that implies an acsriptive. (p. 276)

However, the fourth approach, namely 'to speak appropriately on God within different contexts (representative speaking)', which Louw (2014:276) adds to Braaten's three modes of God's language (1989), is critical in this study. This is because, in theology, particularly in pastoral assessment:

[W] hether we speak about, of, for, to or on God, our main task is hermeneutical, i.e. to determine the significance of God-talk with regard to the human quest for meaning. (Louw 2014:276)

Accordingly, linking with Louw's approach of appropriately speaking on God (2014), a biblical redemptive historical approach in dealing with migrant ministries can be contended and proposed. Its utility lies in providing a coherent-unifying approach, resulting in an appropriate and constructive understanding as Louw (2014:276) rightly argues. It pays special attention to the storyline of the Bible, namely creation, fall, redemption and consummation. Vos (1980:7-13), who taught biblical theology at Princeton Seminary from 1893 to 1932, and Gaffin (2012) are some of the few leading proponents of biblical redemptive historical approach.

In building upon Vos's conception of redemptive historical approach (1980), Gaffin (2012:92) endorses the redemptive historical approach as the best methodology of interpreting Scripture. He (Gaffin 2012:92) articulates that 'history is revelation and develops six elements of the redemptivehistorical approach' and strongly maintains that the 'outcome of these elements is that Jesus Christ is the culmination of the history of redemption'. Gaffin's (2012:91-92) six elements are as follows: (1) the Bible should always be interpreted in view of God's self-revelation (in word and deed) in creation; (2) God's redemption or revelation is historical; (3) Jesus Christ, in his person and work centred on his death and resurrection (e.g. 1 Cor 15:3-4), is the culmination of the history of redemption (revelation); (4) the subject matter of revelation is redemption, meaning that 'revelation - excluding prefall, pre-redemptive revelation in Eden - is the interpretation of redemption, as revelation either attests or explains, describes or elaborates'; (5) Scripture is self-revelation, not somehow less revelation; and finally (6) hermeneutically, revelation is the interpretation of redemption. The significance of Gaffin's aforementioned six elements of the redemptive historical approach (2012:109) lie in the fact that 'salvation resides ultimately, not in who God is or even in what he has said, but in what he has done in history, once and for all, in Christ'. Gaffin's redemptive historical approach (2012) can be summarised as advancing the study of any particular topic in the Bible, in view of the doctrines of creation, fall and redemption, with their culmination in Christ.

Likewise, Torrance (2008:45), Horton (2011:45) and Kruger (2007:2) advance the redemptive historical approach as an appropriate method of studying the Bible and treats the Old and New Testaments as a single unit that finds its fulfilment in Jesus Christ's person and work. In view of the abovementioned discussion, we argue that a biblical redemptive historical approach can be summarised as advancing the study of any particular topic in the Bible in view of the doctrines of creation, fall and redemption, with its culmination in Christ. In his $\mathrm{PhD}$ thesis titled Theological understandings of migration and church ministry models: A quest for holistic ministry to migrants in South Africa, Magezi (2018:28) specifically advances the biblical redemptive historical approach as an appropriate method in studying migration in the Bible. He (2018:28) contends that, in studying migration, the biblical historical redemptive approach is preferred, because migration is widespread in the Bible and that what it says on migration has unity. Thus, one needs a biblical redemptive historical approach to the matter. This is because it helps to bring out the relationship of anything that the Bible touches on with its central message or the so-called bigger picture, which is redemption (Magezi 2018:28). Stated otherwise, the biblical redemptive historical approach helps to mainstream anything that the Bible teaches on, whereas other approaches tend to allow for many other things to be studied as if they were peripheral to the central message of the Bible, which is salvation of humankind (Magezi 2018:28).

Given this, in developing a biblical-theological understanding of Ezra-Nehemiah, the command to the Israelites to divorce foreign wives, as in Ezra-Nehemiah, will be analysed in view of the biblical redemptive framework established in this section. However, before that can be done, the manner in which the Israelites dealt with intermarriage in the previous cases will be highlighted by looking at the narratives of Rahab and Ruth.

\section{The conceptualisation of the marriage of Israelite men to foreign women and their (gentile women's) roles in biblical redemptive history}

In view of the intermarriage of the men of Israel to gentile women who have been converted to Israel's faith and way of life in the Old Testament, the narratives of Rahab and Ruth 
can be specifically mentioned. These two women from gentile ethnic groups are embraced in Israel and later on incorporated in the leading line of Israel. They play significant roles, together with many others, in advancing the genealogy of Jesus. The stories of Rahab and Ruth are reminiscent of the fact that God migrates his people (Israel) to accomplish his redemptive purposes and plans for humankind. That is to say, after the physical redemption of the Israelites from the Egyptian bondage, God migrates them to Canaan so that there would be a remnant of people among the gentile nations that God, in his providence, planned to graciously save and even, over time, incorporate into Israel to work out his plans.

The story of Rahab (a Canaanite woman or a woman from a gentile ethnic group) in Joshua 2:1-21 (cf. 6:17, 22, 23, 25) illustrates that God, in his providence, migrates the Israelites to Canaan so as to graciously save a remnant of gentile people, which he later on uses to advance his redemptive purposes and plans for humankind. In saying the abovementioned, the author of this article is aware that when God migrates the Israelites from Egyptian bondage in order to enable them to possess the land of Canaan, he commands them to completely exterminate the inhabitants of the land of Canaan, including men, women and children (Dt 7:2; 20:17). The Israelites are a people or nation ruled by God; thus, the extermination of the Canaanites is a direct command that is given to them by God (Geisler 1977:99-100). However, from a closer look at Deuteronomy 7 and 20, it seems the reason for the total destruction of the Canaanites is to prevent the Israelites from falling into idolatry. In this way, from a redemptive historical approach, it can be argued that the Canaanites and other nations that gave up their gods and acknowledge Israel's God as the only true God to be worshipped were not supposed to be destroyed, as they were not a threat to the faith of the Israelites, that is, they could not corrupt the Israelites to worship their pagan gods, becaues they were now part of the faith of Israel.

With the aforementioned in mind, God's command to the Israelites to exterminate the Canaanite nations should be read in view of the redemption that God aims to execute through Abraham, Isaac, Jacob and the Israelites as a nation. By implication, the story of Rahab indicates that from the universal redemption that God sets to accomplish through the Israelites, the latter are not commanded to exterminate all, but only those that resisted and did not want to accept living under them and in serving the only true God of Israel. For instance, Rahab, a prostitute in Jericho, hears about the God of Israel and acknowledges him as the one who is worth risking her life for and she hides the spies of Israel who come to spy on the land of Jericho (Magezi 2018:52-55). One should note that the spies of Israel, sent by Joshua to Jericho (Jos 2:1-2), come to the house of Rahab and lodge there for a night. The report about the Israelite spies reaches the king of Jericho (Jos 2:3). When the king of Jericho realises that the spies had been at Rahab's house, he demands that Rahab (the prostitute) brings them out of her house. Rahab, however, lies that they had gone; yet, she had hidden them on the rooftop of her house (Jos 2:4-6). Rahab sends the soldiers of Jericho, who want to pursue the spies, in the opposite direction.

It is clear in Joshua 2:8-11 that Rahab had given up her pagan gods and acknowledged the God of Israel as the only true God, based on his (the God of Israel) works that she had heard. In addition, Rahab pleads with the spies of Israel to spare her and everyone in her household (Jos 2:12-14). The spies of Israel swear an oath to spare Rahab and her household members as long as she would not disclose the former's mission to the authorities or anyone in Jericho. Later on, a pitched battle is fought between Israel and Jericho, and the city of Jericho is destroyed. In line with the oath that the spies had made to Rahab, Joshua gives an order for Rahab and all her household members to be rescued (Jos 6). Hence, Rahab and her household members, in this case, are rescued and adopted by the Israelites and dwell among the Israelite community. Given this, it can be possibly advanced that the migration of the Israelites from Egyptian bondage to Canaan is not outside of God's plan and control, because, in his providence, God uses that migration to save the remnants of the gentile nations such as Rahab. Indeed, Rahab is converted. Hebrews 11:31 mentions Rahab as one of the heroines of faith in the Old Testament. Rahab's story reaches its climax when she marries Salmon and gives birth to Boaz (Mt 1:5) who later marries a Moabite woman, Ruth. Ruth is the mother of Obed, the father of Jesse, who sires David, from whom Jesus, the Saviour of the world, descends (Mt 1:1-16).

Furthermore, Ruth is one of the converted foreign women who marry into one of the leading lines of Israel and advance the genealogy of Jesus (Rt 1-4). The background of Ruth's narrative is that because of famine in the land of Judah, Elimelech, the man of Bethlehem in Judah (with his wife Naomi and two sons, Mahlon and Chilion), migrates to Moab and settles there (Rt 1:1-2). Elimelech dies, after which his two sons get married to Moabite women, namely Orpah and Ruth (Rt 1:3-4). Naomi and her two sons live in Moab for 10 years after the death of Elimelech (Rt 1:4b). However, the sons also die, leaving Naomi bereft of husband and sons (Rt 1:5). After the death of her husband and sons, Naomi leaves Moab for Judah with Ruth (her daughter-in-law), after hearing the good news that the covenantal God of Israel had visited his people of Judah and given them food (Rt 1:6-7; Ulrich 2007: 53). Given God's provision of food for the people of Judah, Naomi sets to return to Judah and advises her two daughters-in-law to return to their fathers' houses and remarry (Rt 1:8-18). Orpah returns, but Ruth insists on going with Naomi. Because of Ruth's insistence, Naomi finally migrates with her to Judah at the beginning of the barley harvest season (Rt 1:19-22).

Ruth 1:16-18 seems to express that Ruth is already a converted Moabite woman who is conveying her faith. In this regard, it can be argued that when Elimelech migrates to Moab, he and his family are in a way certainly some kinds of 'missionaries' by word and deeds to many Moabites. Ruth could have been 
converted when she married Elimelech's son. The words of Naomi to her daughters-in-law suggest that they would be going back to their people and their gods when leaving hers, which suggests that when they were with her during their marriages to her sons, they had declared some allegiance to her God. Thus, when Ruth affirms that the covenantal people of God (the people of Naomi) will be her people and the covenant God (the God of Naomi and Israel) will be her God (Rt 1:16-18), it is possible at this point that Ruth is expressing her faith in the God of Israel that she had acknowledged and believed when she got in contact with Elimelech and his family.

However, when Ruth goes to Judah with Naomi (her motherin-law), she gets married to Boaz who belongs to the leading lineage of Israel and fosters the genealogy of Jesus. After marrying Boaz, Ruth gives birth to Obed, the father of Jesse, who fathers David (Rt 4:17), who becomes the king of Israel and with whom God enters into an eternal covenant about his (David's) throne which was made to endure forever (2 Sm 7ff.). The genealogy in Matthew also amplifies David's genealogy in Ruth 4:18-22 by making a significant link between Jesus Christ (the Saviour of all people) and David, as it denotes Jesus as the Davidic son (Mt 1:1-25). It is in Ruth 4:17 and Matthew's genealogy where the inclusion of Ruth as part of Jesus' genealogy is perceived.

Given this, we argue that these two women of gentile ethnic origin, Ruth and Rehab, come to be in Matthew's genealogy in order to play a crucial role together with many others, because they are embraced by the Israelites and later on incorporated into the leading line of Israel when they marry Israelite men. With this in mind, the divorce of foreign women in Ezra-Nehemiah requires a lens of a biblical redemptive framework, because what the Bible says about the intermarriage of the Israelite men to foreign women has unity with the central message of the Bible, which is redemption.

\section{Towards migration biblical- theological understanding of Ezra- Nehemiah \\ Consideration of Ezra-Nehemiah in view of biblical redemptive historical approach}

In bringing the overall theme of the book of Ezra to the fore in view of the biblical redemptive historical approach, Breneman (1993:56) argues that Ezra 1:1 confronts the Israelites with their covenant God who faithfully keeps his covenant promises. In Ezra 1:1-3, God fulfils Jeremiah 25:11's prophetic words to the Israelites by redeeming Judah from Babylonian captivity through the use of Cyrus as his (God's) agent of that great redemption for God's covenantal nation, Israel (Ezr 1:1-3). Cyrus, the Persian king, is anointed by God to carry out the redemption of the Israelites from Babylonian captivity. When Cyrus comes into power, he passes a decree for all the Israelites to go back to their homeland and build the temple of the Lord and worship him (God). In doing this, the prophet Jeremiah's prophecy about the captivity of Israel and its redemption is fulfilled. Thus, although there is no frequent reference to the prophets in Ezra, it is apparent that the author of Ezra is cognisant of the messages of the prophets, because he links the return of the Israelites from Babylonian captivity to the fulfilment of Jeremiah's prophecy (Breneman 1993:56-57). Fyall (2010) concurs with Breneman (1993) when he argues that Ezra reminds the Israelites (especially, Ezr 10:1-8) about their future, which is intrinsic to their covenantal relationship with God:

The importance of the covenant and its renewal cannot be overstated. God is faithful and while by no means clearing the guilty, welcomes back the repentant sinner. The covenant of God is unilateral, a gift of grace to which we contribute nothing. (p. 131)

However, Ezra 9-10 and Nehemiah 13:25-27 confront us with the need for the remnant of Israelites who return from Babylonian captivity to separate themselves from the people of the land (Breneman 1993:57). Snyder (2012) argues that the people of the land are held:

In dread (Ezra 3:3) and negatively associated with opposition to the rebuilding of the temple. Nehemiah is equally harsh. He forbids all foreigners from entering the temple: when the people heard the law, they separated from Israel all those of foreign descent (Nehemiah 13:3). (pp. 140-141)

In Ezra 4, the people of the land who are against the rebuilding of the temple are the Samaritans, Ammonites, Ashdodites and Arabs (Snyder 2012:141). However, in focusing on the divorce of the foreign wives by the Israelite men returning from Babylonian captivity, it can be advanced that the officials of Israel approached Ezra, the priest, with the problem of the remnant of men of Israel that were marrying foreign wives (Ezr 9:1, cf. Neh 13:25-27). The issue is that when the Israelites had gone into Babylonian captivity as a form of punishment for their (the Israelites) sins by God, many groups of people such as the Moabites, Egyptians, Amorites and Ammonites had come to occupy the land of Israel (cf. Ezr 9:1-2; Japhet 2006:111). Therefore, when the remnant of Israelites come back from Babylonian captivity into their homeland, they find these groups of people in their land. In this way, the of are living in a mixed culture in which they are supposed to maintain their distinct identity as covenant people of God. But the remnant of men of Israel do not maintain their distinctive identity as the covenantal people of God, because they have been taking Moabite, Egyptian, Amorite and Ammonite women as wives (Ezr 9:1-2). Because of this, Ezra sees that the remnant ${ }^{1}$ (cf. Ezr 9:14) of Israel is still disobedient. Thus, Ezra, the priest, (Ezr 10:10, 16) is 'engaging in priestly work as he instructs people about their uncleanness and points to the remedy, along the lines of Leviticus 10:10-11' (Allen \& Laniak 2003:79).

At this juncture, it is important to highlight that scholars have proposed many reasons for Ezra-Nehemiah's command 1.The word remnant (seerit) in Ezra 9:14 is the same word used in Jeremiah $31: 7$ (Breneman 1993:57). 
for the returnees to divorce their foreign wives. For example, Allen and Laniak (2003:79), and Japhet (2006) argue that Ezra 9 and 10 demonstrate that the intermarriage between the returnees from Babylon and the women from 'the peoples of the land' is a serious breach of the covenant, because it makes the land that God had given them as a treasured possession impure (Ezr 9:11-12). That is, these scholars argue that the reason for advocating divorce is to preserve the exclusive identity of the land as God's, for the remnant of Judah, as well as that of the returnees as a covenantal people of God. In other words, they contend that Ezra-Nehemiah command the remnant of Israelite men married to foreign women to divorce them in order to preserve the land ownership within the remnant of Judah, ensuring that the land could not become the possession of the foreigners who had occupied it during the Israelites' time in exile, or from those who had not experienced the judgement of exile (and so had not been purified). Nonetheless, although this can be an attractive argument, this article advances that it is problematic, because, if the inheritance of land was the issue, why could it not be solved by invoking the stipulations in the law around inheritance? Thus, the aforementioned scholarly position cannot be sustained in view of the context of Ezra-Nehemiah.

Farisani (2004:41) also points out that the story of the separation of the Jews, who returned from exile, from the people of the land and foreign wives is one-sided and oppressive, because he perceives that there was no piece of Jewish religious law that could validate the dismissal of foreign wives. However, even if it were there, Farisani (2004) argues that the Persians would not have allowed such an unpopular law to occur in Israel. Hence, Farisani (2004) concludes that the exclusion of both peoples of the land in the rebuilding of the temple and the divorce of foreign wives by the returnees were results of ethnic constructions and the abuse of ethnicity for Ezra and Nehemiah's own ends (Farisani 2004:43-44). Nevertheless, the problem with Farisani's (2004) interpretation of Ezra-Nehemiah is his argument that the other side of Ezra-Nehemiah's narrative is not told and therefore, the story is one-sided, because there is no Jewish religious law that could have allowed the divorce of foreign wives. In doing this, Farisani (2004) seems to deny the authenticity of the narrative of Ezra-Nehemiah regarding the command of divorce. The flaw in Farisani's (2004) approach lies in its potential to cause people not to seriously take the proposed sections of Ezra-Nehemiah and thus downplaying the narrative.

This position can also be linked with Usue's argument (2012:158-169) that the women that Ezra 9-10 speaks about are not foreigners as presupposed by Ezra and Nehemiah. Usue's position (2012) seems to be motivated by his failure to have a comprehensive understanding of Ezra 9-10 in view of the Abrahamic and Mosaic covenants' codes about the inclusion of foreigners. At this juncture, while Usue (2012:167) charges Ezra and his associates for possessing a narrower view of Abrahamic and Mosaic covenant codes, we can also charge him for the same problem. In our view,
Ezra-Nehemiah's command for the Israelite returnees to divorce foreign wives is a true and well-told story. Ezra and Nehemiah also speak about the divorce of real foreign women who were married to the Israelite returnees. Otherwise, by advancing that there is another side of the story that is not told or that Ezra and Nehemiah are not speaking of foreign wives, both Farisani (2004) and Usue (2012) seem to claim to know the details of the story better than the authors who lived and participated in that particular historical context.

Furthermore, Allen and Laniak (2003:79), Fensham (1982:135), Holmgren (1987:85) and Breneman (1993:158) do not view this issue of divorce from a biblical redemptive historical approach. In their different ways, they advance that the prohibition of the remnant of Israelites to marry foreign wives is an obligation that God lays plainly for them in the Torah. Ezra's radical solution for the Israelites returning from Babylon to divorce their foreign wives is inspired by Deuteronomy 7:1-6 and $23: 2-7$ as part of the covenant obligations for the Israelites (Allen \& Laniak 2003:79; Breneman 1993:158). At this juncture, Deuteronomy 7:1-6 speaks about what God expects the Israelites to do when they conquer the foreign nations in the Promised Land that he (God) is about to give them. As the Israelites conquer the foreign nations and take the land as their treasured possession from God, Deuteronomy 7:1-6 commands the Israelites to do the following things: (1) to completely destroy the foreign nations such as the Amorites, the Canaanites, Perizzites, Hittites et cetera; (2) not to enter into a covenant with the foreign nations; and finally (3), not to intermarry with the foreign nations (Japhet 2006:111). In analysing aforesaid command and prohibitions, Ford (2017:167) posits that the Canaanites are not a military threat to Israel, because, if God is with Israel, it is automatic that the Canaanites will be defeated. The religious danger is that the Israelites are prone to be tempted to follow the pagan gods of the Canaanites and therefore compromise their relationship with God. This arises from the explicit warnings about the Canaanites that God gives to the people of Israel before they possess the land of Canaan (cf. 1:26-31; 2:24-25; 3:21; 7:1724; 9:1-13 \& 20:1; Ford 2017:167). Together with Ford (2017), it can be emphatically argued that the reasons for such warnings are:

Such behaviour is abhorrent to YHWH (Deut. 12:31; cf. 18:12; 20:18; it is a snare for Israel (Exod. 23:33, 34:12; Deut. 7:16), and it will lead to their destruction (Deut. 6:14-15, 7:4; 8:19). This extreme danger is the context in which YHWH commands the destruction of the Canaanites. Israel must do whatever it takes to avoid idolatry. The specific outworking of this destruction focus on two main areas: a prohibition against intermarriage, and the command to destroy their religious paraphernalia. (p. 167)

In view of the prohibition of the Israelites to intermarry with the foreign nations, the reason was that the foreign wives would cause the children of Israel to abandon their covenant obligations, that is, to follow God and serve him wholeheartedly (Dt 7:4). Given this, it is concluded that the 'the returned exiles under Ezra's instruction took seriously 
God's commandments' by putting this law into practice (Breneman 1993:158). This implies that:

Ezra issued a call for confession and reform, interpreting the latter step as the divine will. Separation from the peoples of the land necessitated separation from the foreign wives in order to maintain the exclusive status of a community made up, in principle of returned exiles and their families. (Allen \& Laniak 2003:80)

However, from the biblical redemptive historical approach, we differ from the conception of Allen and Laniak (2003:79), Fensham (1982:135), Holmgren (1987:85) and Breneman (1993:158). From a biblical redemptive historical approach, the issue in the passage is not just marriage to people from other nations or aliens; it is about what kind of aliens one can get married to. In other words, it is about exercising care to ensure that one gets married in the Lord. The matter, even in the earlier Bible passages, is that of faith, because we have perceived the Israelite men marrying the gentile women as exemplified by the marriages of Boaz to Ruth (Rt 4) and Rahab to Salmon (Mt 1:5), which the Bible does not condemn as $\sin$. In other words, these women of gentile ethnic origin (Ruth and Rahab) were married in the leading line of Israel and mentioned with others as playing a significant role in the genealogy of Jesus, the Saviour of all people, Jews and gentiles. Therefore, from a biblical redemptive historical approach, this article argues that the issue in Ezra-Nehemiah is that of accepting and getting married to people who are not converted or committed to the faith and life under God.

Here, unconverted foreign women would cause the Israelites to abandon their covenant obligations, that is, to follow God and serve him wholeheartedly (Dt 7:4). This can be substantiated when one brings to the fore the fact that Ezra and Nehemiah are conscious of the consequences that befell Solomon due to marrying unconverted foreign wives, because it is given in Nehemiah 13:26-27 as the basis of motivating the returnees to divorce foreign wives (this also applies to Ahab's marriage to foreign wives in $1 \mathrm{Ki} \mathrm{16-19).} \mathrm{In}$ amplifying the aforesaid, it can be avowed that in 1 Kings 11:1-11, King Solomon marries unconverted foreign women whom he allows to bring their idols, even to Jerusalem, and eventually lead him to worship pagan gods. Therefore, this article contends that the case of Solomon is indeed given in Nehemiah 13:26-27 (cf. also Ahab in $1 \mathrm{Ki} \mathrm{16-19)} \mathrm{as} \mathrm{a}$ motivation for the remnant of Israelite men married to unconverted foreign wives to divorce them. In this way, the biblical redemptive historical approach advances that EzraNehemiah's command of divorce pertains to the remnant of Israelites that were married to unconverted foreign wives.

\section{Integrating the Old and New Testament perspectives regarding Christians' intermarrying non-believers}

In integrating the aforementioned message of Ezra-Nehemiah with the New Testament, this article argues that in the broader context of 2 Corinthians 6:14-7:1 in which Paul is dealing with many problems in the Corinthian church, he exhorts Christians 'to turn away from idolatrous practices to a mode of life consistent with their profession, faith in Christ as their Saviour' (Janbaz 1997:2). In Janbaz's view (1997), the issue here is primarily about the marriage of Christians to non-believers, although it does not apply to marriage alone, but to all aspects of life. To use Janbaz's words (1997) on 2 Corinthians 6:14-16:

We are instructed then not to be joined with those who are without faith, referring at this point primarily to marriage, but introducing a much wider application to any situation where our faith is in danger of being compromised. When we study the seventeenth verse it will become evident that the command of verse fourteen cannot apply to marriage alone. (p. 2)

Using Janbaz's conception (1997) of 2 Corinthians 6:14-16, we argue that the matter in Ezra-Nehemiah has not changed, even today, because Christians are commanded to marry fellow believers, irrespective of whether the person is of alien origin or not (2 Cor 6:14; Janbaz 1997). To use Paul's own words in 2 Corinthians 6 :

Do not be bound together [unequally yoked] with unbelievers; for what partnership have righteousness and lawlessness, or what fellowship has light with darkness? (v. 14)

However, we are conscious of scholars such as Starling (2013:60), who argues that the principal issue which Paul refers to in 2 Corinthians 6:14 'is not the cultic or sexual entanglements he addresses elsewhere but the fleshly thinking that has distorted their assessments of Paul ...' Furthermore, Theron and Lotter (2008:281-303), in their article titled 'Do not be yoked together with unbelievers: New Testament perspectives on how Christians should live and act in a society of diverging convictions', argue that 2 Corinthians 6:14 does not pay special attention to the issue of Christian marriage to unbelievers. Instead, they use this passage to establish the general relationships and responsibilities of Christians towards the unbelieving world. However, as our intention is not to get into a 2 Corinthians 6:14-7:1 debate due to space constraints, we concur with Janbaz (1997) by affirming that believers, even today, should not marry unconverted people.

This can be further substantiated by 1 Corinthians 7:12 (and further) that encourages divorce when in a mixed marriage to a partner that has allegiance to other gods. The Scripture draws on the implications of such unions by showing how Solomon was demanded to support the religious activities of his wives (cf. Abera 2010:36ff.; Pierce 2009:10ff.). With the aforementioned in mind, it is logical to concur with Cave (2003:181) that the lesson the church can draw from EzraNehemiah is that 'it is so easy for things to creep into the life of the church through wrong relationships and unholy alliances'. That is, when things that have nothing to do with God move into the body of Christ '... it does not take long for the rot to set in ... Holiness is not negotiable, cleanse the temple' (Cave 2003:181). In this way, God's command for his people to marry people of the same faith (regardless of their ethnic, tribal, linguistic and national background) is a pervasive teaching in the Old and New Testaments as this 
article has established. That is to say, from a biblical redemptive historical approach, Ezra and Nehemiah foster the inclusion of migrants into the Israelite society. However, they forbid the returnees from marrying unconverted people and this also applies to today's church in the New Testament.

\section{Towards principles and guidelines for migrant ministry}

The focus of this article is to develop a theological understanding that fosters inclusion and embrace integration of migrants from a seemingly explicit xenophobic books of Ezra-Nehemiah. This entails developing a theological understanding that has practical implications on real life from texts that could be perceived as encouraging exclusion of migrants. The development of a systemic and integrated theological understanding should not necessarily be an end in itself, particularly on practical issues such as migration, but a process to encourage practical action. Therefore, there is a need to pose the following question: What is the implication of the discussion to a practical migrant ministerial approach that fosters migrant inclusion, embrace and integration? Several applications can be drawn from the preceding discussion. However, in the context of this article, four major overarching principles could be discerned and proposed. The first principle indicates a practical application to the internal church relationships and functions while the three principles provide practical insights on the design of a migrant ministry that has implications for the church and the public:

- The first principle suggests that within a context of migration where people from different backgrounds and religions intermix and intermarry, the church has to be clear about the principles that inform their interrelationships. Marriage is a critical relationship forming institution that has to be well considered and informed by clear principles. The above discussion of Ezra-Nehemiah from a biblical redemptive historical approach revealed a threat that arises from the intermarriages of Christians with individuals who are unconverted to the Christian faith. In view of the discussion of Ezra-Nehemiah, foreign women symbolised unconverted people who would possibly cause them to abandon their covenant obligations and fail to serve God wholeheartedly (Dt 7:4). This suggests that conversion to one's religion and possibly culture is a critical condition to allow one to marry an individual from a different region and background (e.g. Ruth and Rahab). This is arguably applicable to most religions. This position seems tenable and substantiated from the above discussion in that conversion to one's religion, seemed to be a proxy indicator ${ }^{2}$ for devotion and loyalty.

- The second to the fourth principles provide three intertwined principles for a migrant ministry (as shown

2.The argument made in the discussion (of Ezra-Nehemiah) explicitly and implicitly is culture and religion in their were intertwined. Conversion entailed embracing the religion and culture of the other, which, in this case, is the God of Israel. It is noted that this position and interpretation can be contested. However, the conversion discussion in the Old Testament is not within the focus of this article. in Figure 1). From a biblical redemptive framework in Ezra-Nehemiah, these three principles are intricately linked and should be understood as three connected and interactive sectors of one wheel, and serve as important guidelines that are drawn from a biblically and theologically informed migrant ministry. The second to fourth principles are telos [goal], embrace and integration.

- The second principle is telos that relates to goals and intentions. The question related to telos is: What should be the underpinning goals and intentions that inform migrant interventions? From the employed theological framework, it has been argued that the telos of Israel was to be God's instrument of salvation to all nations on earth. Ruth and Rahab stands as vivid examples of this goal. They were integrated into God's salvific purpose. As demonstrated from the argument above, the discouragement from marrying foreign women in EzraNehemiah was not necessarily about the women's foreignness as such, but their threat to God's salvific purpose and goal. Thus, the defining matrix for coexistence and marriage seemed to be participation in a clear goal, which, in this case, is the honour of Yahweh. Accordingly, guided by the notion of telos, the discussion above indicated that embedded in migration, should be recognition and discernment of God's purpose in the process. In our day, this approach could be viewed as simplistic and problematic. This approach can easily be tantamount to pushing one's agenda on migrants claiming that it is God's purpose. However, the notion of God's purpose and goal can be sustained theologically. In whatever situation that people find themselves, it is imperative to discern God's purpose. This includes migration. At country level, migrants should participate in the purposes and goals pursued in that country such as national development plans and others. Within the

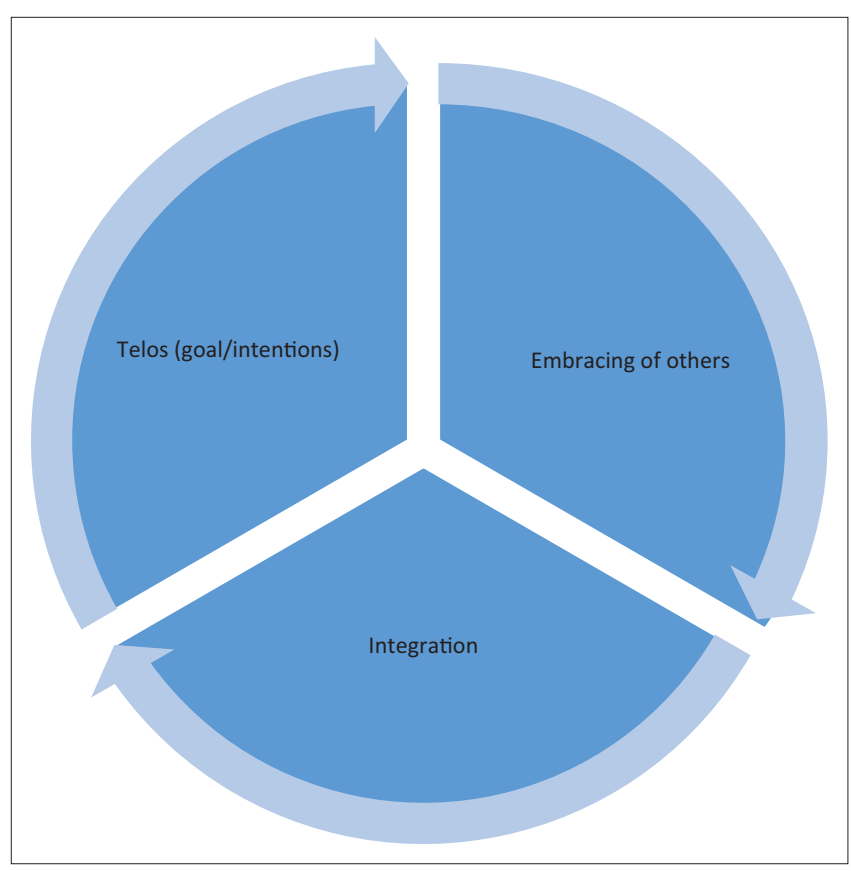

FIGURE 1: Overarching migrant ministry lessons Ezra-Nehemiah. 
context of Ezra-Nehemiah, the goal entailed the honour of God without deviation or compromise. Furthermore, within Reformed Christianity, the notion of God's telos is linked to God's glory. Hence, migration providentially serves the purpose of God's glory. The notion of God's salvific purpose suggests that the Christian's goal is salvation. Every situation serves God's purposes. Among Christians, Ezra-Nehemiah provides a goal, a compass for life within the migration and intermixing of people, where all situations should serve the purposes of God. Within this understanding, migration happens within God's providential hand for his purposes. However, at humanistic level, migrants' humanity should be respected. Host and migrant should intermix in a manner that upholds the humanity of all people as espoused by the Universal Declaration of Human Rights.

- Linked to purpose and goal is embracing other people, which is the third principle. As argued from our theological framework, embracing other people from other nations should be done guided by a clear common goal. From Ezra-Nehemiah, the foreign women who did not uphold, threathened God's purpose. Embracing other people should not result in abandoning one's goals and purposes. Embracing other human beings entails welcoming and accepting people from other places, which denotes hospitality. It also means avoiding being judgemental of other people, because they appear different or queer. It further entails overcoming stereotypes and prejudices about other human beings. Lastly, embracing others is about cultivating diversity within a global village, where humanity is united and bonded by a sense of our universal humanity, as well as the bond of Christ. Thus, human beings embrace each other mutually pursue goals that further human flourishing.

- The fourth principle is integration, which is about living together or being one. It is about co-existence, sharing the same spaces and resources in oneness. It is also about being part of a family or society. Integration is about infusing someone into your space. It thus includes notions such as assimilation. When people are integrated, divisions and separations disappear. From our theological perspective, far from being exclusive, Ezra-Nehemiah suggests inclusion. However, the inclusion should flow from a common purpose, which in Ezra-Nehemiah is a salvation purpose for all people. Integration thus should not result in abandoning the set goals and purposes. It is common that efforts to embrace and integrate migrants may sometimes end up breaking the laws of a country. For instance, Rev Paul Verryn at the Johannesburg Central Methodist Church ended up breaking South African laws when criminal migrants took advantage of the situation (Mail \& Guardian 2010).

\section{Conclusion}

Ezra-Nehemiah presents a challenge of understanding a text perceived as excluding migrants and xenophobic.
Yet, considered from a biblical redemptive historical approach, the text fosters the inclusion of migrants. Thus, reading from a biblical redemptive historical approach, the text encourages embracing and integration. Notwithstanding the encouragement to embrace and integrate other people, the migration and intermixing of people pose challenges that should not be viewed simplistically. There is a clear rise in nationalism across nations (e.g. president Trump's notion of making America great again, Brexit challenges and xenophobic issues in South Africa) within our global context. The rising nationalism threatens and poses huge rifts among nations, resulting in diffusing the notion of a unified telos. Thus, within this situation, embracing and integrating with others, remain challenges; yet, they are also opportunities for us to practise true humanity. Migration, both at theological and social levels, presents humanity with enormous challenges, as well as incredible opportunities for being fully human to one another. Among theologians, the quest to develop relevant theological frameworks should continue. There is a need to engage problematic texts such as divorce of foreign women in Ezra-Nehemiah to develop a life-giving and human affirmation of other people.

\section{Acknowledgements Competing interests}

The authors declare that no competing interest exist.

\section{Authors' contributions}

All authors contributed equally to this work.

\section{Ethical consideration}

This article followed all ethical standards for carrying out research without direct contact with human or animal subjects.

\section{Funding information}

This research received no specific grant from any funding agency in the public, commercial, or not-for-profit sectors.

\section{Data availability statement}

Data sharing is not applicable to this article as no new data were created or analysed in this study.

\section{Disclaimer}

The views and opinions expressed in this article are those of the authors and do not necessarily reflect the official policy or position of any affiliated agency of the authors.

\section{References}

Abera, A.A., 2010, 'Practical implications of 1 Corinthians 7:1-16 for Christian married couples in the Ethiopian Full Gospel Believer's Church', MTh thesis, South African Theological Seminary, Johannesburg.

Allen, L. \& Laniak, T., 2003, Ezra, Nehemiah, Esther, Hendrickson Publication, Peabody, MA. (New International Commentary). 
Braaten, C.E., 1989, 'The problem of God language today', in C.E. Braaten (ed.), Our naming of God: Problems and prospects of God-talk today, pp. 11-33, Fortress, Minneapolis, MN

Breneman, M., 1993, Ezra, Nehemiah, Esther: An exegetical and theological exposition of Holy Scripture, Broadman \& Holman Publications, Nashville, TN. (The New American Commentary).

Cave, D., 2003, Discovering Ezra-Nehemiah: Crosswell Bible guides, 2nd edn., Crossway Books, Leicester.

Demarest, B.A. \& Lewis, G.R., 1987, Integrative theology, Academie Books, Grand Rapids, MI.

Farisani, E., 2004, 'Ethnicity in Ezra-Nehemiah', Theologica Viatorum 28(1), 24-55.

Fensham, F.C., 1982, The Books of Ezra and Nehemiah, William B. Eerdmans Publishing Company, Grand Rapids, MI.

Ford, W., 2017, 'The challenge of the Canaanites', Tyndale Bulletin 68(2), 161-184.

Fyall, R., 2010, The message of Ezra \& Haggai: Old Testament, InterVarsity Press, Nottingham.

Gaffin, R., 2012, 'Redemptive-historical view', in S.E. Porter \& B.M. Stovell (eds.) Biblical hermeneutics: Five views, pp. 91-109, IVP Academic, Downers Grove, IL.

Geisler, N.L., 1977, A popular survey of the Old Testament, Baker House, Grand Rapids, MI.

Graham, E.L., 2017, 'On becoming a practical theologian: Past, present and future tenses', HTS Theological Studies 73(4), a4634. https://doi.org/10.4102/hts. v73i4.4634

Holmgren, F.C., 1987, Ezra and Nehemiah: Israel alive again, William B. Eerdmans Publishing Company, Grand Rapids, MI. (International Theological Commentary).

Horton, M., 2011, Christian Faith: A systematic theology for pilgrims in the way, Zondervan, Grand Rapids, MI.

International Organisation for Migration (IOM), 2015, World migration report 2015, viewed 23 May 2016, from http://www.un.org/en/.../migration/.../migrationreport /.../MigrationReport2015_Highlights.p.

Janbaz, J.E., 1997, 'The doctrine of separation as taught in 2 Corinthians 6:14-7:1' WRS Journal 4(1), 1-7.

Japhet, S., 2006, From the rivers of Babylon to the highlands of Judah: Collected studies on restoration period, Eisenbrauns, Winona Lake, IN.

Kruger, B., 2007, On the road to becoming flesh: Israel as the womb of the incarnation in the theology of T.F. Torrance, viewed 12 July 2019, from https://www. perichoresis.org.

Louw, D.J., 2014, Wholeness in hope care: On nurturing the beauty of the human soul in spiritual healing, LIT Press, Zurich.
Magezi, C., 2017, 'Migration crisis and the church: A response to lacunae and considerations for Christian ministry engagement', Verbum et Ecclesia 38(1), a1671. https://doi.org/10.4102/ve.v38i1.1671

Magezi, C., 2018, 'Theological understandings of migration and church ministry model: A quest for holistic ministry to migrants in South Africa', PhD thesis in Theology, North-West University, Potchefstroom.

Magezi, V. \& Magezi, C., 2018, 'Migration crisis and Christian response: From Daniel De Groody's image of God Theological Prism in Migration theology to a Migration practical theology ministerial approach and operative ecclesiology', HTS Teologiese Studies/Theological Studies 74(1), 4876, https://doi.org/10.4102/hts.v74i1.4876

Mail \& Guardian, 2010, 'Paul Verryn: What went wrong?', 29 January, viewed 08 April 2020, from https://mg.co.za/article/2010-01-29-paul-verryn-what-went-wrong/.

Miller-Mclemore, B.J. \& Couture, P.D., 2003, Poverty, suffering and HIV/AIDS, Cardiff Academic Press, Cardiff.

Murray, J., n.d., 'The inspiration of the scripture', Westminster Theological Journal, viewed 19 April 2019, from 73-104. https://d3h3guilcrzx4v.cloudfront.net/ uploads/images/files/WTJ/Murray,\%20John\%20-\%20The\%20inspiration\%20 of $\% 20$ Scripture.pdf.

Pierce, R.W., 2009, 'First Corinthians 7: Paul's neglected treatise on gender', Priscilla Papers 23(3), 8-13.

Schwartz, R.M., 1997, The curse of Cain: The violent legacy of Monotheism, University of Chicago Press, Chicago, IL.

Snyder, S., 2012, Asylum-seeking, migration, and Church Farnham, Surrey, Ashgate, Burlington, VT.

Starling, D., 2013, 'The ärı ıтol of 2 Cor 6:14 Beyond the Impasse', Novum Testamentum 55(1), 45-60. https://doi.org/10.1163/15685365-12341406

Theron, P.M., \& Lotter, G.A., 2008, 'Do not be yoked together with unbelievers: New Testament perspectives on how Christians should live and act in a society of diverging convictions', In die Skriflig 42(2), 281-303. https://doi.org/10.4102/ids.v42i2.268

Torrance, T.F., 2008, Incarnation: The person and life of Christ, IVP Academic, Downers Grove, IL.

Ulrich, D.R., 2007, From famine to fullness: The gospel according to Ruth, P \& R Pub, Phillipsburg.

Usue, E., 2012, 'Is the expulsion of women as foreigners in Ezra 9-10 justifiably covenantal?', Acta Theologia 32(1), 158-169. https://doi.org/10.4314/actat.v32i1.8

Vos, G., 1980, Redemptive history and biblical interpretation: the shorter writings of geerhardus vos, in B.R. Gaffin (ed.), Presbyterian and Reformed Publishing, Phillipsburg, NJ.

Williamson, H.G.M., 1985, Ezra, Nehemiah, Word Books, Waco. (World Biblical Commentary). 